\title{
Pemanfaatan Sabut Pinang sebagai Kombinasi Filter Multi Media-Sabut Pinang (FMM-SP) di Perumahan Valensia Muaro Jambi dan Uji Kualitas Air Bersih
}

\author{
Reny Safita ${ }^{1}$, Fery Kurniawan ${ }^{1}$, Deliza ${ }^{2 *}$ \\ ${ }^{1}$ Program Studi Tadris Biologi, UIN Sulthan Thaha Saifuddin Jambi, Jambi, Indonesia \\ 2Program Studi Kimia, UIN Sulthan Thaha Saifuddin Jambi, Jambi, Indonesia
}

Corresponding Author:

Deliza

deliza@uinjambi.ac.id

Received: February 2021

Accepted: August 2021

Published: September 2021

CDeliza et al. This is an open-access article distributed under the terms of the Creative Commons Attribution License, which permits unrestricted use, distribution, and reproduction in any medium, provided the original author and source are credited.

\begin{abstract}
This study aims to help the residential community of Valencia, Muaro Jambi to get clean water using filter multi media-sabut pinang (FMM-SP). Multimedia filtration is a method of water treatment by utilizing soil as the main medium which is shaped like brick blocks and arranged alternately between zeolites. The LMM-FSP reactor is made of used gallons, $40 \mathrm{~cm}$ high, $28 \mathrm{~cm}$ in diameter, containing brick blocks $(12 \times 7 \times 4) \mathrm{cm}$ consisting of a mixture of volcanic soil, charcoal, areca fiber, iron powder (70:10:10:5) \%, permeable layer used zeolite $(1-3 \mathrm{~mm})$. The samples came from the wells of residents of Valencian housing, Muaro Jambi, Jambi City. The research was carried out with variations in the mass of areca nut into the filter, flow rates of $5,10,15,20 \mathrm{~mL} /$ minute and two ways, namely aeration and non-aeration. FMM-SP efficiency for the aeration process at a flow rate of $5 \mathrm{ml} / \mathrm{min}$ with $\mathrm{pH}$ parameters; Smell; Nitrite; Nitrate; turbidity; $\mathrm{Mn}$; Fe in order is 7.5; Odorless, $60.30 \%$; $59.33 \%$; $59.33 \%$; $70.10 \% ; 73.20 \%$, and in non-aerated $\mathrm{pH}$ 7.3; Odorless; $50.82 \%$; $48.37 \%$; $60.91 \%$, Fe $61.20 \%$ From all the efficiency values for decreasing the parameters, it can be said that it meets the requirements for clean water.
\end{abstract}

Keywords: multimedia layer of areca coir filter, areca nut, zeolite, well water, clean water quality

\section{Pendahuluan}

Menurut Water Environment Patnership in Asia (WEPA), Indonesia merupakan salah Negara terkaya dalam sumber daya air bersih karena menyimpan $6 \%$ potensi air dunia. Air bersih merupakah kebutuhan primer bagi manusia yang keberadaannya diatur dalam pasal 33 UUD 1945 ayat 3 dimana "Bumi dan air merupakan kekayaan alam yang terkandung di dalamnya dan dikuasai oleh Negara dan dipergunakan untuk sebear-besar kemakmuran rakyat. Berarti negara menjamin hak setiap warganya untuk mendapatkan air untuk kebutuhan sehari-hari. Namun tidak begitu adanya di lapangan, kebutuhan air terus naik, tetapi air bersih makin berkurang dan tercemar. Seiring dengan bertambahnya usia bumi bertambah pula penduduk sehinggaberbanding lurus terhadap kebutuhan air bersih. Muaro Jambi memiliki kondisi air tanah berawa dimana Air sumur gali di daerah muaro jambi kualitasnya tidak baik, berbau dan keruh jauh dari persyaratan air bersih, di perumahan Valencia Muaro Jambi khususnya mengalami permasalahan air bersih. Sumber air bersih lain yang di andalakan adalah dari air PDAM. Namun air PDAM sering terkendala jarang 
hidup, jika hidup pun dengan tataletak perumahan yang tidak sama datar sering kali warga bagian ketinggian tidak mendapatkan air bersih. Sehingga mau tidak mau masyarakat membuat sumur galian untuk memenuhi kebutuhan air, meskipun jauh dari syarat air bersih.

Cara lain untuk mendapatkan air bersih masyarakat dapat membeli air dengan harga Rp. 175,000 untuk 1000 L. Hal tersebut dalam jangka panjang hanya dapat dilakukan oleh masyarakat dengan ekonomi menengah keatas, untuk masyarakat ekonomi rendah jelas ini sangat memberatkannya. Kawasan Muaro Jambi yang terdiri dari lahan yang berawa dan gambut, air yang berwarna merah kecoklatan bahkan keruh, $\mathrm{pH}$ rendah kandungan zat organik dan anorganik tinggi. Begitupun kondisinya dengan sungai terbesar di Sumatra ini yaitu sungai Batanghari yang tercemar ${ }^{[1]}$. Dampak dari hal tersebut tentu saja kebutuhan air bersih tidak terpenuhi ${ }^{[2][3]}$.

Beberapa ciri air di kawasan perumahan Valencia Muaro Jambi yang tidak memenuhi syarat air bersih tersebut:

1. Estetika air, air yang berwarna, berbau akan mengurangi efektivitasnya, karena tentu saja secara organik dan anorganik sudah tercemar yang akan memberikan dampak negatif bagi kesehatan jika digunakan.

2. $\mathrm{pH}, \mathrm{pH}$ yang rendah menyebabkan air berasa asam yang dapat berdampak negatif kepada gigi yaitu kerusakan gigi serta sakit perut.

3. Kandungan zat organik dan anorganik yang tentukan sumber makanan bagi mikroorganisme dalam air yang dapat menimbulkan bau begitupun kandungan logam sehingga air tersebut akan memberikan dampak buruk seperti bersifat karsinogen. Tinggi kadar logam tentu akan menjadi hal yang harus diperhatikan.

4. Kandungan Fe dan Mn akan memunculkan warna pada benda-benda dan bahan jika di aplikasikan, misalnya baju putih. Tentu hal tersebut membuat resah masyarakat untuk menggunakannya, kemudian bau dan rasa yang ditimbulkan.
Menurut riset beberapa tahun terakhir telah banyak metoda yang digunakan untuk mengolah air bersih yaitu berupa filtrasi dimana diriset baru-baru ini filtrasi dengan memanfaatkan filter termodifikasi nanokomposit 2D $\quad \mathrm{Ti}_{3} \mathrm{C}_{2} / \mathrm{Al}_{2} \mathrm{O}_{3} / \mathrm{Ag} / \mathrm{Cu}$ yang inovatif dengan potensi aplikasi untuk pengolahan air Point-Of-Use (POU) ${ }^{[4]}$, di kenal juga proses River- bank filtration (RBF) ${ }^{[5]}$, Proses electro-peroxone (EP) yang melakukan pretreatment koagulasi-sedimentasi-filtrasi[6], koagulasi, pengendapan, penggunaan desinfektan, dan lainnya. Namun ditemukan teknik pengolahan air[7][8] yang lebih efektif dinamakan multi media filter layer.

FMM-SP merupakan saringan berlapis yang memanfaatkan sumber daya alam yang ada di daerah Jambi berupa sabut pinang dan tanah vulkanik gunung Kerinci serta arang, sabut pinang, serbuk besi dan zeolit (Gambar 1). Jambi memiliki perkebunan pinang yang luas di Kabupaten Tanjung Jabung Barat, Provinsi Jambi dengan luas perkebunan pinang 17,969 hektar $^{[9]}$ dan dari Badan Pusat Statistik juga melaporkan luas perkebunan pinang di Provinsi Jambi mencapai 2,098,500 ha pada tahun 2017[10]. Namun limbah sabut pinang ini belum di kelola dan dimaanfaatkan dengan baik dan benar, masyarakat membuang begitu saja limbah sabut pinang, selain itu sabut pinang mengandung selulosa yang cukup tingi yaitu $70 \%$. Selulosa mempengaruhi kekuatan dan stabilitas stuktur, semakin tinggi kandungan selulosa maka semakin tinggi kekuatan serapnya. Mampu menyerap pengotor organik dan anorganik dan juga dapat mengabsorsi bau, warna/kekeruhan dan gas. Secara kimia sabut pinang mengandung pektin $25 \%$, pektin oksalat $2 \%$, lignin $26 \%$, flavonoid $52.57 \mathrm{mg} / \mathrm{g}$, dan hemiselulosa[11][11]. Sabut pinang bersifat biodegradable, tidak beracun dan ramah lingkungan yang dapat terurai dengan sendirinya keunggulan daya serap tinggi kemudian memiliki konduktifitas termal yang baik sehingga dapat mengikat logam dengan baik. Maka peneliti memanfaatkan limbah sabut pinang sebagai kombinasi filter perbaikan kualitas air ${ }^{[12]}$ menjadi air bersih[11],[13],[14]. 
Penelitian ini dilakukan untuk nantinya dikenalkan dan melatih masyarakat perumahan Valencia Muaro Jambi khususnya untuk mengatasi permasalahan air dengan mengunakan media FMM-SP dan nantinya terlihat kemampuan media dalam menjernihkan air sumur yang coklat kekuningan keruh untuk menjadi air bersih yang sesuai dengan Peraturan Kesehatan RI Nomor 492/MENKES/PER/IV/ 2010.

\section{Metodologi Penelitian}

\section{Bahan kimia}

Bahan-bahan yang digunakan pada penelitian ini adalah $\mathrm{H}_{2} \mathrm{SO}_{4} 98 \%$, kalium hidrogen ftalat $\left(\mathrm{KHC}_{8} \mathrm{H}_{4} \mathrm{O}_{4}\right) \quad$ (Sigma-Aldrich), kalium dihidrogen fosfat $\left(\mathrm{KH}_{2} \mathrm{PO}_{4}\right)$ (Sigma-Aldrich), dinatrium hidrogen fosfat $\left(\mathrm{Na}_{2} \mathrm{HPO}_{4}\right)$ (SigmaAldrich), natrium hidrogen karbonat $\left(\mathrm{NaHCO}_{3}\right)$ (Sigma-Aldrich), natrium karbonat $\left(\mathrm{Na}_{2} \mathrm{CO}_{3}\right)$, hidrazin sulfat $\left(\mathrm{NH}_{2}\right) 2 . \mathrm{H}_{2} \mathrm{SO}_{4}$ (Sigma-Aldrich), heksametilen tetraamin $\left(\mathrm{CH}_{2}\right) 6\left(\mathrm{NH}_{2}\right)_{4}$ (SigmaAldrich), ferro ammonium sulfat, indikator ferroin, perak sulfat $\left(\mathrm{Ag}_{2} \mathrm{SO}_{4}\right)$ (Sigma-Aldrich), $\mathrm{HCl}$ pekat (Sigma-Aldrich), $\mathrm{MnSO}_{4} .4 \mathrm{H}_{2} \mathrm{O}$, $\mathrm{HNO}_{3}$ pa (Sigma-Aldrich), $\mathrm{KMnO}_{4}$, natrium oksalat $\left(\mathrm{Na}_{2} \mathrm{C}_{2} \mathrm{O}_{4}\right), \mathrm{FeSO}_{4} .7 \mathrm{H}_{2} \mathrm{O}, 1-10$ fenantrolin monohidrat, $\mathrm{NaNO}_{2}, \mathrm{NaCl}$, asam sulfanilat, asam asetat $\left(\mathrm{CH}_{3} \mathrm{COOH}\right)$, naftil etilendiamin dihidroklorida, brusin sulfat dan akuades.
Bahan berasal dari Laboratorium Air, Teknik Lingkungan, Universitas Andalas.

\section{Peralatan}

Alat-alat yang digunakan dalam penelitian ini adalah, reaktor FMM-SP, $\mathrm{pH}$ meter (Trans Instruments), neraca analitik (Camry 200), aerator (Amara, AA-350), pompa vakum (Front Lab FP 300), spektrofotometer UV-Vis (UV-2600 Shimadzu), inductively coupled plasma (ICP-9000) dan alat gelas.

\section{Prosedur penelitian} Reaktor filter multi media-sabut pinang
(FMM-SP)

Reaktor terbuat dari galon akrilik berbentuk tabung dengan diameter $28 \mathrm{~cm}$ dan tinggi 40 $\mathrm{cm}$ (memanfaatkan barang bekas). Penyusun dalam reaktor tediri dari bata yang berisikan campuran tanah vulkanik (kaki gunung Kerinci), arang batok kelapa halus, bubuk besi dan sabut pinang dengan perbandingan (70:10 :10: 5)\%, kemudian dihomogenkan dengan mencampurkan kemudian di bungkus dengan karung goni yang sebelumnya di lakukan perendaman serta di cuci bersih karung goni tersebut kemudian di jahit berbentuk bata. Setelah itu di tata seperti susunan batu bata yang diselingi dengan zeolit antara lapis setebal $3 \mathrm{~cm}$ dan alas dasarnya kerikil (Gambar 1).

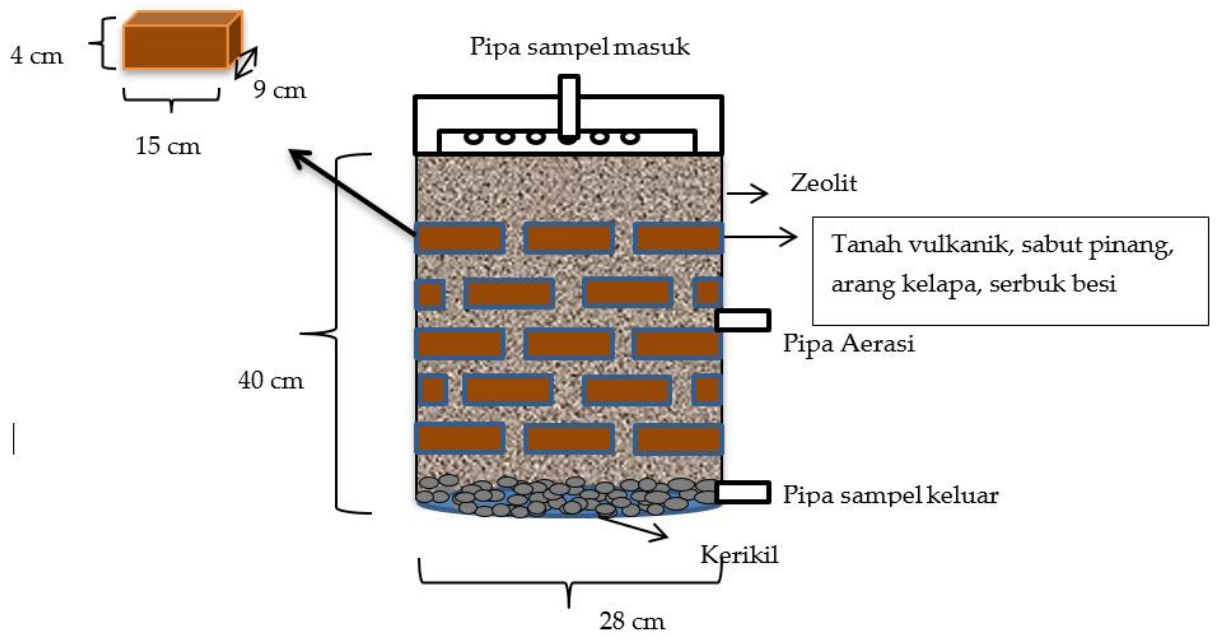

Gambar 1. Rancangan reaktor filter multi media-sabut pinang (FMM-SP). 


\section{Perlakuan terhadap air sumur}

Air sumur di ambil sesuai dengan metode standardisasi Indonesia[ ${ }^{[15]}$.

\section{Pengambilan sampel air sumur}

Dilakukan pengukuran permukaan sampel air sumur dan kedalamannya, kemudian dicatat semua hasil pengukuran. Dilakukan pengambilan sampel air sumur dengan membuka kran air sumur dan biarkan air mengalir selama 1-2 menit kemudian masukan sampel air sumur kedalam wadah kaca coklat.

\section{Metoda analisis}

Metoda analisis sampel dilakukan mengikuti Standar Nasional Indonesia (SNI). Penentuan $\mathrm{pH} \quad$ (SNI 06-6989.11-2004)[16], Penentuan kekeruhan (SNI 06-6989.25-2005)[17], penentuan kadar nitrit (SNI-06-6989.9-2004) ${ }^{[18],}$ penentuan nitrat (SNI 06-2480-1991) ${ }^{[19]}$, penentuan logam mangan (SNI 6989.5-2009)[20], penentuan logam Fe (06-6989.4-2004) ${ }^{[21]}$. Pada penelitian ini terfokus pada logam mangan dan logam $\mathrm{Fe}$ karena pengukuran awal dengan menggunakan inductively coupled plasma (ICP) menunjukan dua logam tersebut yang memiliki kadar yang cukup tinggi.

\section{Penentuan pH (SNI 06-6989.11-2004)}

Dilakukan kalibrasi $\mathrm{pH}$ meter dengan menggunakan larutan penyangga setiap akan melakukan pengukuran pada suhu kamar. Kemudian elektroda dikeringkan menggunakan tisu dan di bilas dengan air suling dan selanjutnya di bilas dengan larutan uji sampel air sumur kemudian celupkan elektroda kedalam larutan uji sampel air sampai pH meter menunjukkan angka pembacaan yang tetap. Selanjutnya dicatat hasil skala yang tertera pada $\mathrm{pH}$ meter.

\section{Penentuan kekeruhan (SNI 06-6989.25-2005)}

\section{Pembuatan larutan standar kekeruhan (formazin)}

Larutan I: larutan hidrazin sulfat $\left(\left(\mathrm{NH}_{2}\right)_{2} \mathrm{H}_{2} \mathrm{SO}_{4}\right)$ dibuat dengan menimbang hidrazin sulfat sebanyak $1.00 \mathrm{~g}$ dan diencerkan dalam labu 100 $\mathrm{mL}$ dengan penambahan akuades. Larutan II:
Ditimbang $1000 \mathrm{~g}$ heksa metilen tetra amin $\left(\left(\mathrm{CH}_{2}\right) 6 \mathrm{~N}_{4}\right)$ encerkan dengan akuades dalam labu $100 \mathrm{~mL}$.

Suspensi larutan induk kekeruhan 4000 NTU dengan cara campurkan $5 \mathrm{~mL}$ larutan I dan 5 mL larutan II di dalam labu $100 \mathrm{~mL}$, larutan didiamkan 24 jam pada temperature $25{ }^{\circ} \mathrm{C}$ kemudia diencerkan dengan akuades dalam labu ukur $100 \mathrm{~mL}$. Suspensi baku kekeruhan 40 NTU dengan cara mengencerkan $10 \mathrm{~mL}$ suspense larutan induk kekeruhan 4000 NTU menjadi $1000 \mathrm{~mL}$ dengan akuades. Larutan di atas disiapkan untuk setiap kali pengujian.

\section{Penentuan kekeruhan dengan spektrofotometer}

Spektrofotometer dihubungkan dengan arus listrik, biarkan sesaat hingga stabil, kemudian dihidupkan alat biarkan kurang lebih 15 menit, set panjang gelombang untuk kekeruhan 420 $\mathrm{nm}$. Masukkan blangko ke kuvet, atur nilai absorban 0.000, kemudian ukur larutan uji standar kekeruhan, lakukan hal yang sama terhadap sampel.

\section{Pengukuran nitrit (SNI-06-6989.9-2004) ${ }^{[18]}$}

\section{Pembuatan larutan standar}

Di buat larutan standar nitrit dengan variasi konsentrasi dengan cara memipet $5 \mathrm{~mL}$ larutan standar nitrit $10 \mathrm{mg} / \mathrm{L}$ masukkan kedalam botol film ditambahkan $1 \mathrm{~mL}$ reagen Saltzman di homogenkan diamkan 30 menit atau sampai terbentuknya warna pink. Diukur absorban dengan spektrofotometer dengan panjang gelombang $550 \mathrm{~nm}$.

\section{Pembuatan larutan sampel}

Dipipit sampel $5 \mathrm{~mL}$ dimasukkan kedalam botol film, ditambahkan $1 \mathrm{~mL}$ reagen Saltzman, aduk dan biarkan 30 menit. Di ukur absorban dengan spektrofotometer dengan panjang gelombang $500 \mathrm{~nm}$.

\section{Pengukuran nitrit dengan spektrofotometer}

Dihubungkan arus listrik ke spektrofotometer, on kan alat biarkan stabil kurang lebih 15 menit, set panjang gelombang kekeruhan 550 $\mathrm{nm}$, kemudian masukan kuvet yang telah berisi 
blangko, diatur absorbannya $0.00 \mathrm{~nm}$, sekanjutnya ukur deret larutan sampel dengan perlakuan yang sama.

\section{Penentuan nitrat (SNI 06-2480-1991)}

$10 \mathrm{~mL}$ air yang jernih ditambahkan $2 \mathrm{~mL}$ larutan $\mathrm{NaCl}, 10 \mathrm{~mL}$ larutan $\mathrm{H}_{2} \mathrm{SO}_{4}$ dan $0.5 \mathrm{~mL}$ larutan brusin-sulfanit kemudian dipanaskan dengan penangas air $95{ }^{\circ} \mathrm{C}$ selama 20 menit. Tambahkan akuades sampai volume $25 \mathrm{~mL}$, setelah itu ukur intensitas dengan spektrofotometer dengan panjang gelombang $420 \mathrm{~nm}$.

Perhitungan:

Konsentrasi nitrat $=\mathrm{A} \times \mathrm{S}=\ldots \ldots \mathrm{ppm}$

Keterangan:

A = absorban sampel

$\mathrm{B}=$ kemiringan kurva kalibrasi (ppm/unit absorban)

\section{Pengukuran logam mangan (SNI 6989.5-2009) ${ }^{[20]}$}

Persiapan larutan sampel mangan terlarut

Disiapkan sampel yang akan di uji, kemudian disaring dengan saringan membran, larutan sampel siap di ukur.

\section{Pengukuran larutan sampel mangan total}

Homogen kan sampel dengan cara memipet 50 $\mathrm{mL}$ sampel ke dalam gelas piala, tutup dengan kaca arloji dan panaskan sampel hingga volume sampel menyusul menjadi $15 \mathrm{~mL}$, jika belum jernih dilakukan penambahan $5 \mathrm{~mL}$ $\mathrm{HNO}_{3}$ pekat kemudian tutup, dilakukan berulang hingga logam terlarut, ditandai adanya endapan putih atau agak jernih, kemudian pindahkan sampel klabu ukur $50 \mathrm{~mL}$ kemudian disaring dan ditambahkan air bebas mineral hingga tanda batas dan homogenkan.

\section{Pengukuran sampel mangan}

Diuji kadar mangan dengan injeksikan kedalam SSA nyala lalu ukur serapan dengan panjang gelombang maksimum.
Perhitungan:

Kadar logam mangan $(\mathrm{Mn})=\mathrm{Mn}(\mathrm{mg} / \mathrm{L})=\mathrm{C} x$ fp

Keterangan:

$\mathrm{C}$ adalah kadar yang didapat hasil pengukuran

(mg/L)

fp adalah faktor pengenceran

Pengukuran kadar Fe(06-6989.4-2004)

Pipet $50 \mathrm{~mL}$ larutan sampel air kemudian dimasukan kedalam gelas piala, tambahkan 4 $\mathrm{mL} \mathrm{HCl}$ dan $2 \mathrm{~mL}$ laruta hidroksilamin 20\% dan ditambahkan $5 \mathrm{~mL}$ akuades, dipanaskan dengan cara ditambahkan batu didih kemudian panaskan sampel menyusul menjadi $10 \mathrm{~mL}$, dinginkan, setelah itu pindahkan kedalam labu ukur $25 \mathrm{~mL}$ ditambahkan buffer asetat dengan $\mathrm{pH} 4$ dan $2 \mathrm{~mL}$ larutan fenantrolin $0.1 \%$, kemudian tambahkan akuades hingga tanda batas, baca serapan pada panjaang gelombang maksimum.

\section{Treatment sampel non aerasi dan aerasi}

Sampel air dialirkan perlahan sebanyak $3 \mathrm{~L}$ kedalam FMM-SP melalui pipa masuk, namun pastikan pipa aliran pipa sampel keluar tertutup, setelah itu atur laju alir sampel keluar dari pipa mengunakan stopwatch sesuai dengan variasi laju alir yang kita ingginkan 5, 10, 15, 20 $\mathrm{mL} /$ menit. Perbedaan dengan aerasi adalah di saat sampel dikeluarkan FMM-SP maka sejalan dihidupkan aerator yg kita lewatkan melalui pipa aerasi.

\section{Hasil dan Diskusi}

Hasil analisis air sumur setelah perlakuan aerasi dan non aerasi pada sistem FMM-SP

\section{Analisis kadar $p H$}

Derajat Keasaman $(\mathrm{pH})$ merupakan parameter kimia penting dalam analisis air dan konsentrasi Ion Hidrogen $\left(\mathrm{H}^{+}\right)$dalam suatu cairan ${ }^{[16]}$. Berdasarkan standar mutu Permenkes 416/MENKES/PER/IX/1990 mengenai persyaratan air bersih standar baku mutu untuk pH adalah 6.5-9.0. 
Pada proses penjernihan air, $\mathrm{pH}$ merupakan indikator penting untuk meningkatkan efisiensi proses penjernihan. $\mathrm{pH}$ awal sampel air sumur adalah 6.4, $\mathrm{pH}$ air yang lebih kecil dari 6.5 dapat meningkatkan korosifitas pada benda logam, menimbulkan rasa tidak enak dan dapat menyebabkan beberapa bahan kimia menjadi racun yang dapat mengganggu kesehatan ${ }^{[22]}$.

Berdasarkan hasil penelitian dapat terlihat dari Gambar 2 Terlihat bahwa analisa $\mathrm{pH}$ pada air sumur berbanding lurus dengan bertambahnya laju alir, hal ini dapat dikatakan nilai $\mathrm{pH}$ pada air sumur dapat meningkat setelah dialirkan ke FMM-SP. Hal tersebut dikarenakan kandungan material dalam FMM-SP mengandung Karbon yang dapat menyebabkan bereaksi dengan asam dalam air sehingga menghasilkan ion hidrogen dan bikarbonat yang dapat mempengaruhi $\mathrm{pH}$. Diperoleh nilai $\mathrm{pH}$ dengan laju alir 5, 10, 15, $20 \mathrm{~mL} /$ menit berturut-turut adalah aerasi: $7.7 ; 7.8 ; 8 ; 8.1$ dan non aerasi 7.2 ; $7.2 ; 7.3 ; 7.3$.

\section{Analisis kadar kekeruhan}

Hasil analisis kadar kekeruhan sampel setelah melewati FMM-SP pada proses aerasi dan non aerasi mengalami penurunan di setiap variasi laju alir. Penurunan terjadi pada proses aerasi, didapatkan hasil yang berada di bawah nilai standar baku air bersih' ${ }^{[2]}$. Hal ini tidak lepas dari pengaruh pompa yang dialirkan pada pipa aerasi yang membuat sampel di dalam FMMSP lebih berinteraksi baik dengan materialmaterial oleh dorongan pompa dan dari fungsi material yang memiliki kemampuan dalam menjernihkan sampel, sabut pinang menjadi filter yang membantu dalam menjernihkan dengan kandungaan selulosa $70 \%$. Efisiensi penurunan yang terjadi pada variasi laju alir (5, $10,15,20) \mathrm{mL} /$ menit secara berturut-turut adalah $80.08 \%, 79.89 \%, 77.88 \%, 75.90 \%$ namun berbeda hal dengan non aerasi tidak memiliki penuruan yang baik dan berada di atas nilai standar baku mutu air bersih.

Dari Gambar 3 Terlihat jelas perbedaan kekeruhan terhadap sampel air setelah dialirkan, hal tersebut secara teori karena sampel yang dialirkan melewati zeolit dan blok tanah, dimana zeolit memiliki pori-pori yang besar sehingga iya mampu menyerap bahanbahan organik yang berfungsi sebagai adsorben, kemudian sabut pinang dapat mengadsorbsi logam berat, hal tersebut sudah berdasarkan penelitian yang dilakukan Paresh Chakravarty ${ }^{[23]}$ dan B. Sheeka Subramani ${ }^{[24]}$ bahwasanya sabut pinang dapat mengadsorpsi logam berat pada limbah cair, kemudian mikroorganisme dari tanah yang memiliki sumber makanan dari serbuk besi juga dapat membantu menguraikan bahan-bahan organik.

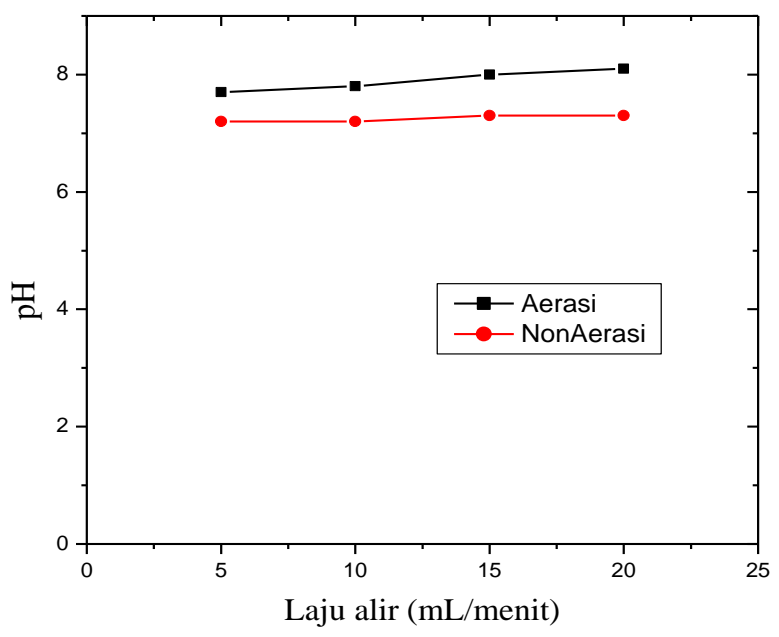

Gambar 2. Kurva nilai $\mathrm{pH}$ sebelum dan setelah dialirkan ke FMM-SP pada proses aerasi dan non aerasi. 


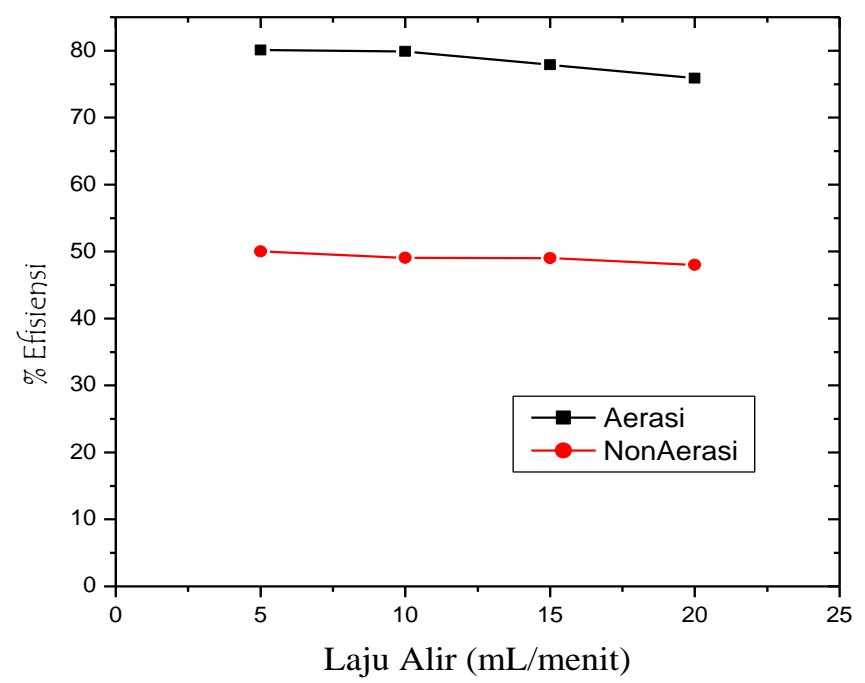

Gambar 3. Kurva efisiensi kekeruhan setelah dialirkan ke FMM-SP pada proses aerasi dan non aerasi.

\section{Analisis kandungan nitrit dan nitrat}

Analisis nitrit dan nitrat perlu dilakukan dan dikembangkan untuk menganalisis dan mengontrol kualitas air bersih. Kualitas dan kuantitas nitrit dan nitrat biasanya dipengaruhi oleh faktor lingkungan dan kedalaman sumur. Senyawa nitrit dan nitrat berasal dari metabolism oraganisme air dan dekomposisi bahan-bahan organik dari bakteri. Nitrit bentuk yang berada antara oksidasi ammonia ke nitrat.

Nitrit mampu mengikat besi dari hemoglobin yang membentuk methemoglobinemia di dalam tubuh. Nitrit dan nitrat merupakan siklus nitrogen, kemudian sumber nitrat dan nitrit dari aktifitas manusia berasal dari penggunaan pupuk nitrogen, limbah organik manusia, terjadi melalui proses fiksasi nitrogen oleh bakteri Rhizobiumi.

Setelah melakukan analisis terhadap air sumur dapat dilihat berdasarkan Gambar 4, nitrat dan nitrit terdeteksi, namun dalam kondisi masi di ambang batas standar air bersih yang dipersyaratkan tentang baku mutu kesehatan air bersih oleh Menteri Kesehatan RI No. 32 Tahun 2017[2],[25]. Setelah dilakukan pengolahan menggunakan FMM-SP pada proses aerasi dan non aerasi berhasil menurunkan kadar dari nitrat dan nitrit tesebut.
Berkurangnya konsentrasi nitrit dan nitrat dari air sumur setelah dilakukan treatment menggunakan FMM-SP pada proses aerasi dan non aerasi. Nampak pada setiap perubahan laju alir memberikan hasil proses nitrifikasi berlangsung dalam kondisi aerobik, pada kondisi tersebut nitrit dioksidasi oleh bakteri Nitrosomonas menjadi nitrat kemudian nitrit pada kondisi anaerob direduksi menjadi nitrogen oleh bakteri anaerob fakultatis yaitu Denitrobacilus serta Nitosococcus. Nitrit memperlihatkan ketidakstabilan di lingkungan sangat mudah berubah-ubah menjadi nitrat dalam sampel air sumur yang di olah yang berada pada air permukaan dengan konsentrasi kecil, namun pada air tanah terdapat pada konsentrasi yang besar. Nitrat dalam air muncul karena ada di alam kemudian dapat muncul dari $\mathrm{N}_{2}$ atmosfer maupun dari pupukpupuk oksidasi $\mathrm{NO}^{2-}$ karena berada pada kelompok bakteri Nitrobacter. Dari sampel air sumur di ketahui kadar nitrat dalam air sumur memiliki konsentrasi lebih tinggi dibandingkan nitrit hal tersebut menandakan bahwasanya suklus nitrogen di alam masih berlangsung baik karena nitrat di alam lebih stabil dari pada nitrit. Air sumur jenis golongan air tanah memiliki tingkat kontaminasi bergantung pada kedalaman air. Di dapat kadar nitrat dalam air sumur $4.25 \mathrm{mg} / \mathrm{L}$ sementara nitri $0.39 \mathrm{mg} / \mathrm{L}$. 

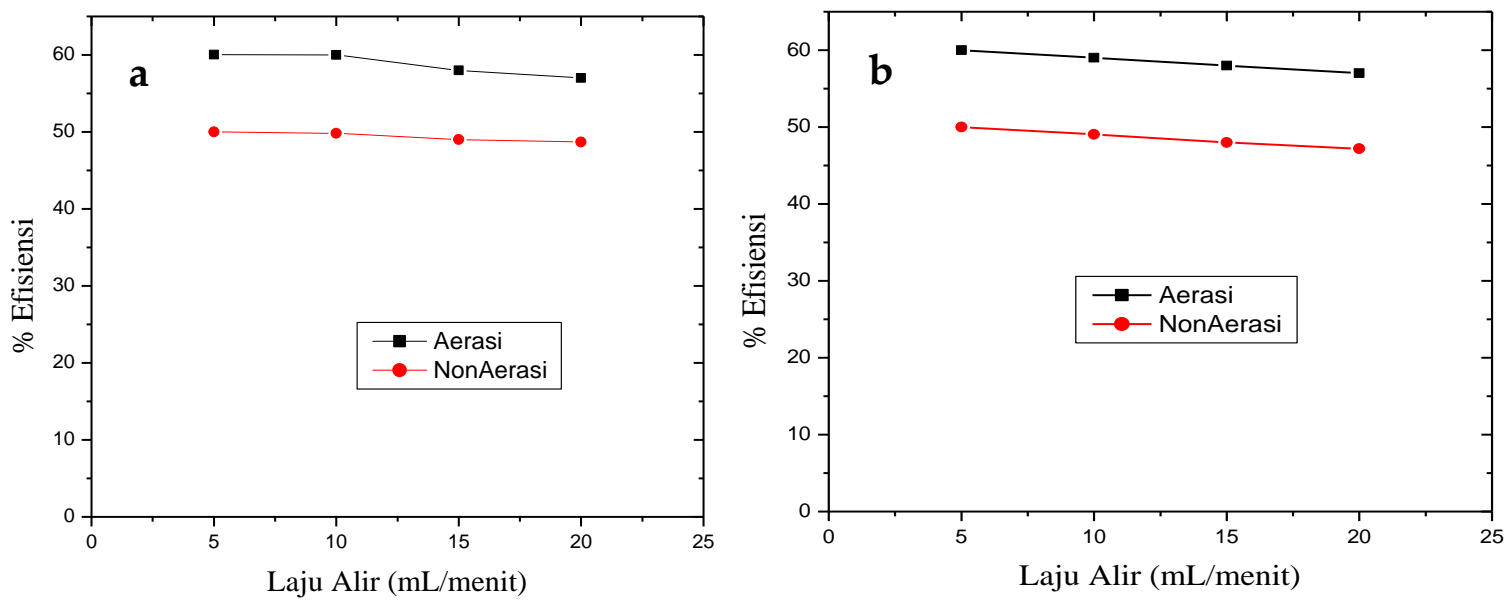

Gambar 4. a) kurva efisiensi nitrit, b) kurva efisiensi nitrat setelah perlakuan setelah dialirkan FMMSP pada proses aerasi dan non aerasi.

\section{Analisis kandungan logam Mn}

Logam mangan merupakan salah satu logam yang banyak di permukaan bumi, yaitu sekitar $0.1 \%$ pada kerak bumi. Mangan di alam tidak dijumpai dalam bentuk murni, melainkan sebuah komponen yang lebih dari 100 mineral. Mangan banyak muncul di air permukaan dan air tanah, hal tersebut mengganggu manusia karena manusia banyak beraktivitas memanfaatkan air, hal tersebut berdampak negatif munculnya kontaminasi mangan dalam $\operatorname{air}^{[2]}$. Mangan sendiri dapat berikatan dengan nitrat, sulfat, dan klorida dan larut dalam air. Mangan yang terkandung dalam air sumur apabila dimaanfaatkan untuk mencuci pakaian menibulkan noda dan apabila mangan dengan konsentrasi kecil dapat menimbulkan rasa tengik dan kandungan logam Mn dalam air bersifat karsinogen ${ }^{[26]}$.

Dari Gambar 5. Dapat dijelaskan kandungan mangan pada air sumur setelah di ukur sebelum dilakukan pengolahan yaitu 0.146 $\mathrm{mg} / \mathrm{L}$, kadar tersebut berada di bawah ambang batas persyaratan air bersih yaitu $0.5 \mathrm{mg} / \mathrm{L}$ namun alangkah lebih baik jika bisa lagi dikurangi. Air sumur setelah dialirkan ke FMM-SP memiliki penurusan hal tersebut memperlihatkan FMM-SP sangat efisien dimanfaatkan untuk mengolah air sumur supaya air sumur menjadi bersih dan dapat dibuktikan dengan perbandingan tingkat efisiensi penurunan kadar mangan dalam air sumur dengan proses bantuan secara aerasi dan non aerasi, kondisi optimum di dapat dengan pengolahan yang memanfaatkan aerasi.

Dikarenakan pada proses aerasi menfaatkan pompa udara menggunakan alat aerasi dapat memperlancar aliran yang mengakibatkan logam mangan yang terkandung pada air sumur tersebut beroksidasi sehingga menjadi mangan oksida dengan valensi yang tinggi sehinga ion mangan terlarut menjadi berkurang.

\section{Analisis kandungan logam Fe}

Keberadan logam Fe dalam air bersifat terlarut, sehingga menyebabkan air berwarna coklat kuning kemerahan, menjadikan air sumur tersebut berbau dan adanya lapisan minyak. Kadar logam Fe yang berlebihan juga menimbulkan karat apabila digunakan untuk membersihkan peralatan yang terbuat dari logam ${ }^{27]}$. Kandungan logam Fe di alam pada kadar tertentu dibutuhkan oleh organisme hidup, tapi berbeda hal jika kandungan tersebut dengan konstrasi tinggi, akan mengakibatkan efek racun. Hasil penurunan kadar logam Fe dapat dilihat pada Gambar 6. 


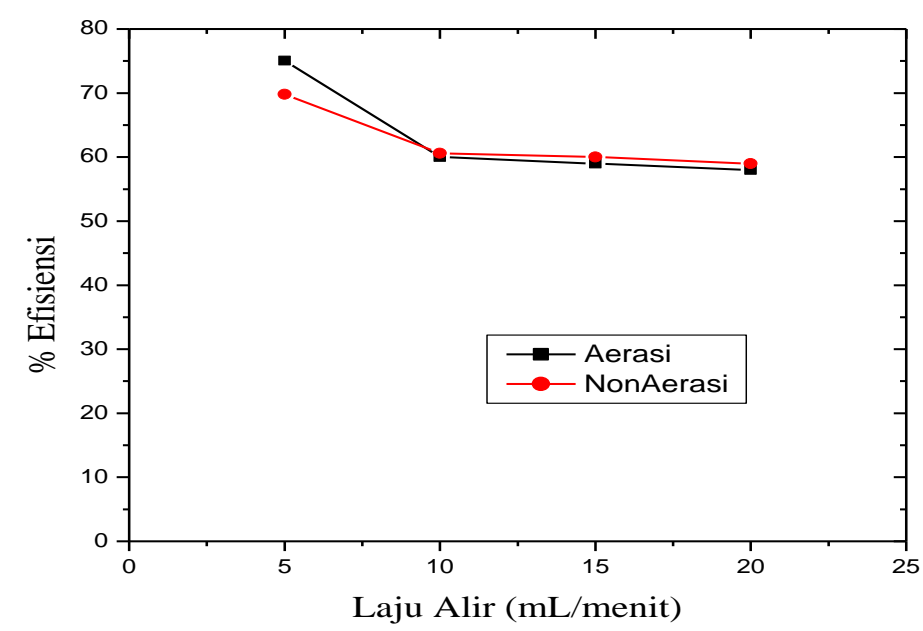

Gambar 5. Kurva efisiensi logam Mn setelah dialirkan ke FMM-SP pada proses aerasi dan non aerasi.

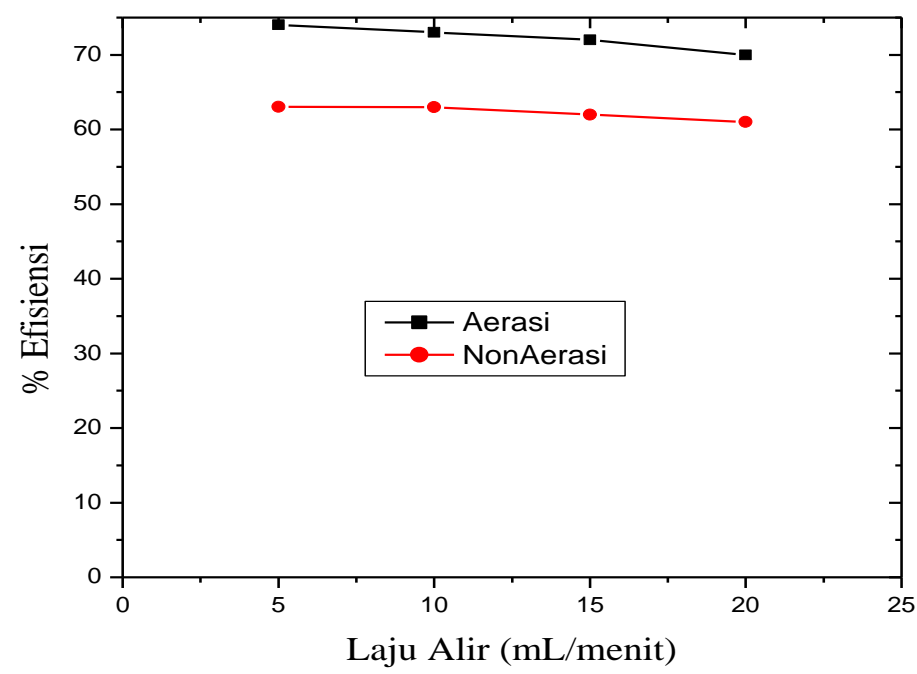

Gambar 6. Kurva efisiensi logam Fe setelah dialirkan ke FMM-SP pada proses aerasi dan non aerasi.

Kandungan logam Fe pada air bersumber dari air rawa dan air gambut serta sisa hasil industri. Kadungan logam itu sendiri pada sampel air sumur memiliki nilai di atas ambang batas persyaratan air bersih yaitu $1.2 \mathrm{mg} / \mathrm{L}$. Dengan ambang batas yang persyaratkan kemenkes $1 \mathrm{mg} / \mathrm{L}^{[2][28]}$.

\section{Kesimpulan}

Setelah di lakukan penelitian menggunakan FMM-SP secara aerasi dan non aerasi, memperlihatkan sistem ini mampu menjadikan sampel air sumur perumahan Valensia Muaro Jambi dapat teratasi, hal tersebut dibuktikan dengan hasil persen efisiensi yang didapatkan. Sebagai berikut:

1. Analisis $\mathrm{pH}$ dengan $\mathrm{pH}$ awal 6.4 setelah di alirkan FMM-SP diperoleh nilai $\mathrm{pH}$ dengan laju alir 5, 10, 15, $20 \mathrm{~mL} /$ menit berturut-turut adalah aerasi: $7.7 ; 7.8 ; 8 ; 8.1$ dan non aerasi 7.2; 7.2; 7.3; 7.3. Terlihat FMM-SP dapat meningkatkan nilai $\mathrm{pH}$. 
2. Berdasarkan Permenkes 416/MENKES/PER/ IX/1990 mengenai persyaratan air bersih standar baku mutu air sumur perumahan Valensia sebelum melewati FMM-SP parameter $\mathrm{pH}$, kekeruhan, nitrat dan nitrit, logam Mn dan Fe belum layak sebagai air bersih. Efisiensi FMM-SP yang di campur dengan sabut pinang dalam pengolahan air sumur secara aerasi dengan variasi laju alir $5,10,15,20 \mathrm{~mL} /$ menit pada parameter $\mathrm{pH}$ 7.5; tidak berbau; nitrit $60.30 \%$, nitrat $59.33 \%$, Mn $70.10 \%$, Fe $73.20 \%$ dan pada non aerasi $\mathrm{pH}$ 7.3; tidak berbau, nitrit $50.82 \%$, nitrat $48.37 \%$ Mn $60.91 \%$, Fe $61.20 \%$ Dari semua nilai efisiensi penurunan parameter sudah bisa dikatakan menuhi untuk syarat air bersih.

\section{Ucapan Terima Kasih}

Terima kasih atas dukungan finasial oleh Universitas Islam Negeri Sulthan Thaha Saifuddin Jambi.

\section{Daftar Pustaka}

1. Deliza, D., Syukri, A., Wulanda, M. N. \& Sartika, D., Detection of metal elements within inductively couple plasma emission Jambi batik waste and views as muslim education. in Journal of Physics: Conference Series, 1869(1): 012059 IOP Publishing Ltd, (2021).

2. Menteri Kesehatan Republik Indonesia., Standar baku mutu kesehatan lingkungan dan persyaratan kesehatan air untuk keperluan higiene sanitasi, kolam renang, solus per aqua, dan pemandian umum. Peraturan Menteri Kesehatan RI, No. 32 (2017).

3. Menteri Kesehatan Republik Indonesia., Persyaratan kualitas air minum. Peraturan Menteri Kesehatan RI, No. 492 (2010).

4. Jakubczak, M., Karwowska, E., Rozmysłowska-Wojciechowska, A., Petrus, M., Woźniak, J., Mitrzak, J. \& Jastrzębska, A. M., Filtration materials modified with $2 \mathrm{~d}$ nanocomposites-a new perspective for point-of-use water treatment. Materials (Basel)., 14(1): 1-16 (2021).

5. Ahmed, A. K. A. \& Marhaba, T. F., Review on river bank filtration as an in situ water treatment process. Clean Technol. Environ. Policy, 19(2): 349-359 (2017).

6. Wang, H., Sun, L., Yan, K., Wang, J., Wang, C., Yu, G. \& Wang, Y., Effects of coagulation-sedimentation-filtration pretreatment on micropollutant abatement by the electro-peroxone process. Chemosphere, 266: 129230 (2021).

7. Rasool, K., Pandey, R. P., Rasheed, P. A., Buczek, S., Gogotsi, Y. \& Mahmoud, K. A., Water treatment and environmental remediation applications of twodimensional metal carbides (MXenes). Mater. Today, 30: 80-102 (2019).

8. Latrach, L., Ouazzani, N., Masunaga, T., Hejjaj, A., Bouhoum, K., Mahi, M. \& Mandi, L., Domestic wastewater disinfection by combined treatment using multi-soil-layering system and sand filters (MSL-SF): A laboratory pilot study. Ecol. Eng., 91: 294-301 (2016).

9. Balai Penelitian Tanaman Palma., Pinang betara. Puslitbang Perkebunan-Badan Litbang Pertanian-Kementerian Pertanian, (2017).

10. Badan Pusat Statistik Provinsi Jambi., Luas tanaman perkebunan menurut jenis tanaman dan kabupaten/kota (hektar). (2017).

11. Sampathkumar, D., Punyamurthy, R., Bennehalli, B., Ranganagowda, R. P. \& Venkateshappa, S. C., Natural areca fiber: Surface modification and spectral studies. J. Adv. Chem., 10(1): 2146-2161 (2014).

12. Azma, A. \& Zhang, Y., Application and development of instrumental analysis in water quality analysis. in The 5th National and 3rd International Conference of Environmental Sciences, Agriculture and Natural Resource, 1-19 Symposia, (2021).

13. Begum, H. A., Haque, A. K. M. M., Islam, M. D., Hasan, M. M., Ahmed, S., Razzak, M. \& Khan, R. A., Analysis of the adsorption of toxic chromium (VI) by untreated and chitosan treated banana and areca fiber. J. Text. Sci. Technol., 6(2): 81106 (2020).

14. Dhanalakshmi, S., Ramadevi, P. \& Basavaraju, B., A study of the effect of chemical treatments on areca fiber 
reinforced polypropylene composite properties. Sci. Eng. Compos. Mater., 24(4): 501-520 (2017).

15. Badan Standardisasi Nasional., Air dan air limbah-Bagian 58: Metoda pengambilan contoh air tanah. SNI 6989.57 (2008).

16. Badan Standardisasi Nasional., Air dan air limbah-Bagian 11: Cara uji derajat keasaman $(\mathrm{pH})$ dengan menggunakan alat pH meter. SNI 06-6989.11 (2004).

17. Badan Standardisasi Nasional., Air dan air limbah-Bagian 25: Cara uji kekeruhan dengan nefelometer. SNI 06-6989.25 (2005).

18. Badan Standardisasi Nasional., Air dan air limbah-Bagian 9: Cara uji nitrit (NO2-N) secara spektrofotometri. SNI 06-6989.9 (2004).

19. Badan Standardisasi Nasional., Air dan air limbah-Bagian 79: Cara uji nitrat (NO3-N) dengan spektrofotometer UV-visibel secara reduksi kadmium. SNI 6989.79 (2011).

20. Badan Standardisasi Nasional., Air dan air limbah-Bagian 41 : Cara uji kadar mangan (Mn) dengan Spektrofotometer Serapan Atom (SSA) secara ekstraksi. SNI 066989.41 (2005).

21. Badan Standardisasi Nasional., Air dan air limbah-Bagian 4 : Cara uji besi (Fe) secara Spektrofotometri Serapan atom (SSA)nyala. SNI 6989.4 (2009).

22. Zheng, B., Zang, L., Li, W., Li, H., Wang, H., Zhang, M. \& Song, X., Quantitative analysis of asbestos in drinking water and its migration in mice using fouriertransform infrared spectroscopy and inductively coupled plasma optical emission spectrometry. Anal. Chim. Acta, 1058: 29-38 (2019).

23. Chakravarty, P., Sarma, N. Sen. \& Sarma, H. P., Biosorption of cadmium(II) from aqueous solution using heartwood powder of Areca catechu. Chem. Eng. J., 162(3): 949955 (2010).

24. Sheeka Subramani, B., Shrihari, S., Manu, B. \& Babunarayan, K. S., Evaluation of pyrolyzed areca husk as a potential adsorbent for the removal of $\mathrm{Fe} 2+$ ions from aqueous solutions. J. Environ. Manage., 246: 345-354 (2019).

25. Menteri Kesehatan Republik Indonesia., Syarat-syarat dan pengawasan kualitas air. Peraturan Menteri Kesehatan RI, No. 416 (1990).

26. Safita, R., Kurniawan, F. \& Deliza, D., Combination of oil palm empty fruit bunch and multi media layer coir filter to treat water in Mendalo Darat, Jambi. in IOP Conference Series: Materials Science and Engineering, 990(1): 012011 IOP Publishing, (2020).

27. Nazir, R., Khan, M., Masab, M., Rehman, H. U., Rauf, N. U., Shahab, S., Ameer, N., et al., Accumulation of heavy metals (Ni, $\mathrm{Cu}, \mathrm{Cd}, \mathrm{Cr}, \mathrm{Pb}, \mathrm{Zn}, \mathrm{Fe}$ ) in the soil, water and plants and analysis of physicochemical parameters of soil and water collected from Tanda Dam Kohat. J. Pharm. Sci. Res., 7(3): 89-97 (2015).

28. Li, J., Li, X. \& Van der Bruggen, B., An MXene-based membrane for molecular separation. Environ. Sci. Nano, 7(5): 12891304 (2020). 